\title{
Foliar condensed tannin levels in lotus species growing on limed and unlimed soils in South-Eastern Australia
}

W.M. KELMAN and G.J. TANNER

CSIRO, Division of Plant Industry, Canberra, Australia

\begin{abstract}
Condensed tannin concentrations $(\%$ of dryweight) were measured in leaves of 22 accessions of Lotus corniculatus, 10 accessions of $L$. pedunculatus, 2 accessions of $L$. tenuis, and 1 accession of $L$. subbiflorus from plants growing on limed $(\mathrm{pH}=5.2)$ and unlimed $(\mathrm{pH}$ $=4.3$ ) soils near Canberra, A.C.T. There was a non-significant decrease in the mean condensed tannin concentration due to liming. The differences between species and between accessions within species were significant. For the $L$. corniculatus entries the range of tannin concentrations over the limed and unlimed sites was $0.15-7.28 \%$, with a mean of $2.09 \%$. The highest concentration was found in the otherwise promising accession CPI 66414. $L$. pedunculatus accessions ranged from 2.53-10.72\% in tannin content, with a mean of $5.99 \%$. Two Portuguese accessions that have promising agronomic features for coastal east Australian pastures had unacceptably high tannin levels- -above $7.50 \%$. Genotypic differences accounted for a large proportion of the total variability for tannin production, so there are good prospects for the improvement of these species by selection and breeding.
\end{abstract}

Keywords Lotus corniculatus, L. pedunculatus, L. tenuis, L. subbiflorus, condensed tannins

\section{Introduction}

Condensed tannins are polymeric flavanol compounds present in the leaf and stem tissue of some leguminous forages. An important property of these compounds is their capacity to bond with leaf proteins and thus prevent the formation of stable foams in the rumen of grazing animals, a condition causing bloat (Jones et al. 1973). Moreover, this protection given to protein in the rumen allows more protein to reach the abomasum and small intestine and thus increase protein utilisation (John \& Lancashire 1981). The actual level of condensed tannins in forage is important because, while beneficial effects may follow their presence, high levels of these compounds lower herbage intake and digestibility (Barry \& Duncan 1984; Chiquette et al. 1988). Thus the production of condensed tannins and their concentrations are important attributes of forages.

The presence and levels of condensed tannins have been documented in several important leguminous forages (Jones et al. 1976; Sarkar et al. 1976; Marshall et al. 1979), but are notably absent in the leaves of lucerne and white clover, the predominant sown legumes of temperate pastures. The genus Lotus is a diverse group of species of wide adaptibility. Cultivated forms are considered bloatsafe because of the presence of condensed tannins in the leaves. In New Zealand, L. pedunculutus is oversown on wet, acid pastures of the south island (Armstrong 1974), whereas the more drought tolerant $L$. corniculatus has been targeted for the high altitude, infertile tussock grassland (Scott \& Charlton 1983). Extensive collections of germplasm have been evaluated more recently (Widdup et al., 1987; Keoghan \& Burgess 1987). The tetraploid $L$. pedunculutus cultivar 'Grasslands-Maku'-is-proving to be a valuable pasture legume in many parts of the world, including the coastal area of south-eastern Australia. In the United States and Canada $L$. corniculatus will grow on dry, infertile, acid soils and a number of cultivars have been developed (Grant \& Marten 1985). The potential of Lotus species in a complementary role with the traditional legumes is now also under investigation in south-eastern Australia (Kelman \& Oram 1989; Schachtman \& Kelman 1991).

Lotus cultivation is thus projected for situations where nutrient shortages or toxicities are likely to occur. These conditions will certainly influence the levels of condensed tannins found in forage and thus affect both the nutrient metabolism and acceptability of stock. Barry \& Forss (1983) have measured higher levels of condensed tannins in forage of Maku (8-11\% of dry weight) growing on infertile soils than on well fertilised soils (2-3\%). However, little is known of the condensed tannin levels in other accessions of this species or their reaction to infertile soils. The aim of this work was to document the variability for condensed tannin production in 4 
species of Lotus growing on limed and unlimed soils at a site in south-eastern Australia. This information will complement studies on dry matter production (Kelman \& Oram 1989) and on salt, aluminium and manganese tolerance (Schachtman \& Kelman 1991) of these accessions to identify those that can be used in Lotus breeding programmes for south-eastern Australia.

\section{Materials and methods}

Ninety-five accessions of Lotus were included in 2-replicate experiments planted on limed and unlimed soils at Ginninderra Experiment Station, near Canberra, A.C.T. in November 1988. Soil pH $\left(0.01 \mathrm{M} \mathrm{CaCl}_{2}\right)$ of the limed site was 5.2 at $\mathrm{O}-10 \mathrm{~cm}$ depth and 4.3 on the unlimed site. The mean soluble aluminium concentration $(0.01 \mathrm{M} \mathrm{CaCl})$ on the limed site was $0.3 \mu \mathrm{g} / \mathrm{g}$, and $4.2 \mu \mathrm{g} / \mathrm{g}$ on the unlimed site. Each accession was represented by 4 plants per plot in a single row. Thirty-five productive accessions were selected for analysis of condensed tannins and forage was sampled in December 1989. Six crown shoots were cut from each plant in each plot in one replicate on the limed and unlimed sites. The plant samples were oven-dried at $80^{\circ} \mathrm{C}$ for 24 hours. After drying, the leaves were separated from the stems and ground to pass through a $1 \mathrm{~mm}$ sieve in a cyclone type mill.

\section{Measurement of condensed tannins}

Assays for total condensed tannins were based on method described by Stafford \& Lester (1986). Condensed tannins were extracted from $50 \mathrm{mg}$ of dried-leaf material in $5 \mathrm{ml}$ of $70 \%$ methanol (v/v) for 2 hours at room temperature. With this material maximum tannin was extracted after 2-3 hours and began to decline after 4 hours. Duplicate extracts were made from leaf tissue of each plant. Ten and 20 $\mu \mathrm{l}$ aliquots of the extract were each pipetted into $13 \mathrm{x}$ $100 \mathrm{~mm}$ culture tubes containing $.1 \mathrm{ml}$ butan-1 ol/hydrochloric acid (95:5 v/v) and $0.1 \mathrm{ml}$ water. The volumes for the 10 and $20 \mu \mathrm{l}$ aliquots were equalised with $70 \%$ methanol. After thorough mixing the tubes were sealed and placed in a waterbath at $95^{\circ} \mathrm{C}$ for 1 hour. The tubes were then cooled immediately in cold water and the absorbance read at $550 \mathrm{~nm}$ in a spectrophotometer. An average

Table 1 Analysis of variance of condensed tannin concentrations in leaves of 35 accessions of Lotus grown in limed and unlimed soils.

\begin{tabular}{lrlc}
\hline & df & MS & F prob. \\
\hline Lime & $!$ & 0.0514 & 0.083 \\
Species & 3 & 0.9482 & $<0.001$ \\
Lime x species & 3 & 0.0070 & 0.729 \\
Accessions of $L$. corniculatus & 21 & 0.0493 & 0.002 \\
Accessions of $L$. pedunculatus & 9 & 0.0458 & 0.014 \\
Accessions of $L$. tenuis & 1 & 0.0034 & 0.646 \\
Residual & 31 & 0.160 & \\
Total & 69 & & \\
\hline
\end{tabular}

absorbance was calculated from the 10 and $20 \mu \mathrm{l}$ aliquots. Each batch of tubes assayed for condensed tannins at one time (25 samples each for the 10 and $20 \mu \mathrm{l}$ aliquots) included 4 control samples. The control samples contained $5,10,15$, or $20 \mu \mathrm{g}$ of condensed tannin purified from leaves of $L$. corniculutus cv. 'Maitland' using the method of Jones et al. (1976). The amount of tannin in extracts was calculated from the linear standard curve.

\section{Analysis of variance}

The log-transformed values of condensed tannin concentrations per plant were averaged for each plot and the means analysed as an unreplicated nested factorial experiment. The lime $x$ accessions interaction mean square was used to test the significance of all sources of variation (Table 1).

\section{Results and discussion}

\section{Lime effect}

Twenty-one of 33 accessions ( $L$. tenuis excluded) had increased tannin levels on the unlimed compared to with the limed site and the mean condensed tannin level over the accessions on the unlimtd site was 3.42 compared with 2.93 on the limed site. However, this difference was not significant (Table 1). Lowther et al. (1987) also found little difference between condensed tannin levels on fertile and infertile soils in 5 L. corniculatus cultivars.

\section{Species effect}

Species differences were very marked. The mean condensed tannin concentration of the $L$. corniculatus accessions over the limed and unlimed sites was $2.09 \%$. that for L. pedunculatus $5.99 \%$ for L. tenuis $0.12 \%$; the single $L$. subbiflorus accession had a mean of $3.16 \%$.

The condensed tannin concentrations for accessions of L. corniculatus (Table 2) are generally in the range reported elsewhere for this species (Lowther et al. 1987; Roberts et al. 1989). Most of the accessions of this species tested here have average tannin levels close to or in the range of $2-4 \%$ of dry weight, which Barry \& Forss (1983) found was the minimum concentration necessary to precipitate protein. The notable exception to this is the accession CPI 66414, in which condensed tannins were close to $7 \%$ on both limed and unlimed sites. Condensed tannin concentrations in the range of 6 to $11 \%$ of dry weight are uncommon in L. corniculutus but have been reported in three accessions from Ethiopia tested by Roberts et al. (1989). The accession CPI 66414 is also unusual in its morphology, differing from other L. corniculatus accessions in its more prostrate, dense growth habit and larger flowers. This type may prove to be better adapted than other L. corniculutus to grazing by sheep in the southeastern Australian regions with modified Mediterranean climates. If so, selection of populations with lower tannin concentrations will be necessary. 
Table 2 Plot means and variability for concentrations of condensed tannins ( $\%$ of dwt) in leaves of 4 species of Lotus on limed and unlimed soils,

\begin{tabular}{|c|c|c|c|c|}
\hline \multirow{2}{*}{$\begin{array}{l}\text { Species/cultivar or } \\
\text { accession number }\end{array}$} & \multirow{2}{*}{ Origin } & \multicolumn{2}{|c|}{ Condensed tannin conc. } & \multirow{2}{*}{$\begin{array}{l}\text { Relative* } \\
\text { variability }\end{array}$} \\
\hline & & Limed & Unlimed & \\
\hline \multicolumn{5}{|l|}{ L. corniculatus } \\
\hline CPI 66414 & Portugal & 7.28 & 7.22 & 0.052 \\
\hline AU Dewey & USA & 3.80 & 2.94 & 0.097 \\
\hline CPI 114291 & Italy & 2.48 & 4.41 & 0.111 \\
\hline CPI 114294 & Israel & 3.00 & 3.71 & 0.197 \\
\hline Quimey & Chile & 2.57 & 2.37 & 0.120 \\
\hline Oberhaunstaedter & Germany & 1.29 & 3.23 & 0.124 \\
\hline HAM298 & & 2.75 & 1.79 & 0.123 \\
\hline CPI 114293 & Italy & 1.82 & 1.96 & 0.162 \\
\hline Vega & USA & 1.23 & 2.45 & 0.086 \\
\hline AT-I & USA & 1.06 & 2.48 & 0.121 \\
\hline CPI 28612 & Spain & 1.23 & 2.16 & 0.087 \\
\hline AT-P & USA & 1.80 & 1.66 & 0.082 \\
\hline CPI 115190 & Brazil & 0.89 & 2.91 & 0.039 \\
\hline HAM299 & Portugal & 1.41 & 1.56 & 0.150 \\
\hline GA-I & USA & 0.79 & 2.13 & 0.101 \\
\hline Ginestrino & Italy & 0.33 & 2.59 & 0.115 \\
\hline Vega II & USA & 1.06 & 1.83 & 0.064 \\
\hline CPI 114301 & Ukraine & 1.42 & 1.25 & 0.117 \\
\hline CPI 36764 & Belgium & 1.68 & 0.21 & 0.233 \\
\hline CPI 115191 & Yugoslavia & 1.26 & 1.35 & 0.168 \\
\hline CPI 114302 & USSR & 0.53 & 1.32 & 0.091 \\
\hline Cree & Canada & 1.04 & 0.15 & 0.137 \\
\hline Species mean & & 1.85 & 2.35 & \\
\hline \multicolumn{5}{|l|}{ L. pedunculatus } \\
\hline CPI 67677 & Portugal & 8.59 & 9.98 & 0.062 \\
\hline CPI 67678 & Portugal & 7.82 & 10.72 & 0.088 \\
\hline P15302 & & 8.75 & 8.21 & 0.081 \\
\hline CPI 67676 & Portugal & 7.20 & 7.73 & 0.084 \\
\hline Grasslands Maku & New Zealand & 4.88 & 5.57 & 0.118 \\
\hline Marshfield & USA & 3.37 & 6.25 & 0.093 \\
\hline CPI 114248 & Chile & 5.80 & 2.92 & 0.194 \\
\hline CPI 114246 & Chile & 5.42 & 2.53 & 0.083 \\
\hline G4704 & New Zealand & 2.57 & 5.32 & 0.050 \\
\hline - Colu m bi a & USA- & 3.75 & 2.63 & $0 . \overline{198}$ \\
\hline Species mean & & 5.82 & 6.19 & \\
\hline \multicolumn{5}{|l|}{ L. tenuis } \\
\hline Tresur Chaja & Argentina & 0.07 & 0.00 & 0.035 \\
\hline CPI 44854 & & 0.07 & 0.32 & 0.091 \\
\hline Species & & 0.07 & 0.16 & \\
\hline \multicolumn{5}{|l|}{ L. subbiflorus } \\
\hline CPI 35903 & Denmark & 2.37 & 3.95 & 0.110 \\
\hline
\end{tabular}

* Relative variability was obtained as the square root of the pooled variance of log-transformed values for individual plants within accessions about their respective means on limed and unlimed treatments.

Within L. pedunculatus the highest condensed tannin concentrations were-present-in CPI 67677 and CPI 67678 and were almost twice the level previously reported to reduce the voluntary intake of Maku (Barry \& Duncan 1984). These two lines, which originate in the Algarve region of southern Portugal, are regarded as promising agronomically for the northern NSW and southern Queensland coastal belt (A. O'Brien, pers. comm.). The Algarve accessions are earlier flowering than Maku and, unlike Maku, can produce seeds in latitudes as low as $26 \%$ But outcrossing and selection of low tannin genotypes will be essential. In contrast to these entries, condensed tannins of cv. 'Columbia', the New
Zealand breeding lines G4704 and CPI 114246 were in the range of 3 to $4 \%$ of total dryweight.

\section{Between-plant variation}

Plant to plant variability within L. corniculatus accessions was generally greater than that of $L$. pedunculatus (Table 2). The variability in $\mathbf{L}$. corniculatus, however, is unlikely to affect animal intake or rumen function. Although dry matter digestibility of L. corniculatus forage with condensed tannins near $5 \%$ is significantly reduced compared to digestibility at 1-2\% (Chiquette et al. 1988), a low frequency of high tannin plants in a population of predominantly low tannin plants is unlikely to affect 
rumen function or intake. In contrast, the variability within the higher tannin producing $L$. pedunculatus accessions may influence condensed tannin levels in variable populations of this species by inducing selective grazing of more palatable low tannin plants.

It was possible, using variance components estimated from the mean squares in Table 1, and the within-plot variance, to quantify the proportion of the total variance attributable to differences between accessions. This value, 0.47 , is not strictly a heritability estimate, but it does indicate the considerable influence that genotype has on the levels of condensed tannins at this site. If confirmed in later studies, the prospects for the genetic alteration of mean leaf tannin concentrations are good. Strong genetic control of condensed tannin production is also evident in the results of Dalrymple et al. (1984) who proposed a single dominant gene for tannin production $(\mathrm{T})$ to account for $\mathrm{F}_{2}$ and backcross ratios of high and low tannin segregants in crosses within $L$. corniculatus. This study prompted the production of isosynthetic strains of this species that differ by $5 \%$ in condensed tannins (Chiquette et al. 1988).

\section{Conclusions}

Condensed tannin concentrations in leaves of most of the accessions of L. corniculatus examined are at levels adequate to prevent bloating, while not adversely affecting dry matter digestibility. However, some Mediterranean populations may contain too much tannin. L. pedunculatus has a wide range of variation within the accessions tested; two Portuguese accessions which are agronomically promising in eastern Australian will require crossing and selection for lower tannin levels.

\section{ACKNOWLEDGEMENT}

We thank Dr R.M. Oram for the supply of the Lotus accessions and his helpful discussions.

\section{REFERENCES}

Armstrong, C.S. 1974. 'Grasslands Maku' tetraploid lotus (Lotus pedunculatus Cav.). NZ journal of experimental agriculture 2: 333-336.

Barry, T.N.; Forss, D.A. 1983. The condensed tannin content of vegetative Lotus pedunculatus, its regulation by fertiliser application, and effect upon protein solubility. Journal of the science of food and agriculture 34: 1047-1056.

Barry, T.N.; Duncan, S.J. 1984. The role of condensed tannins in the nutritional value of Lotus pedunculatus for sheep. 1. Voluntary intake. British journal of nutrition 51: 485-491.
Chiquette, J.; Cheng, K.J.; Costerton, J.W.; Milligan, L.P. 1988. Effect of tannins on digestibility of two isosynthetic strains of birdsfoot trefoil (Lotus corniculatus L.) using in vitro and in sacco techniques. Canadian journal of animal science 68: 751-760.

Dalrymple, E.J.; Goplen, B.P.; Howarth, R.E. 1984. Inheritance of, tannins in birdsfoot trefoil. Crop science 24: 921-923.

Grant, W.F.; Marten, G.C. 1985. Birdsfoot trefoil. In 'Forages, the science of grassland agriculture' (4th ed.). M.E. Heath \& R.F. Barnes (eds). Published by Iowa State University Press. pp. 98-108.

John, A.; Lancashire, J.A. 1981. Aspects of the feeding and nutritive value of Lotus species. Proceedings of the NZ Grassland Association 42: 152-159.

Jones, W.T.; Anderson, L.B.; Ross, M.D. 1973. Bloat in cattle. XXXIX. Detection of protein precipitants (flavolans) in legumes. NZ journal of agricultural research 16: 441-446.

Jones, W.T.; Broadhurst, R.B.; Lyttleton, J.W. 1976. The condensed tannins of pasture legume species. Phytochemistry 15: 1407-1409.

Kelman, W.M.; Oram, R.N. 1989. Responses of perennial Lotus and Astragalus accessions to acid soils. Proceedings 5th Australian agronomy conference, Perth. p.628.

Keoghan, J.M.; Burgess, R.E. 1987. The search for an improved Lotus pedunculatus for the high country pastoral systems. Proceedings of the NZ Grassland Association 48: 125-129.

Lowther, W.L.; Manley, T.R.; Barry, T.N. 1987. Condensed tannin concentrations in Lotus corniculatus and L. pedunculatus cultivars grown under low soil fertility conditions. NZ journal of agricultural research 30: 23-25.

Marshall, D.R.; Broue, P.; Munday, J. 1979. Tannins in pasture legumes. Australian journal of experimental agriculture and animal husbandry 19: 192-l 97.

Roberts, C.A.; Beuselinck, P.R.; Derks, J.A.; Marek, S.M. 1989. Tannins in Lotus corniculatus accessions. Lotus newsletter 20: 38-41.

Sarkar, SK.; Howarth, R.E.; Goplen, B.P. 1976. Condensed tannins in herbaceous legumes. Crop Science 16: $543-546$

Schachtman, D.P.; Kelman, W.M. 1991. Potential of Lotus germplasm for the development of salt, aluminium and manganese tolerant pasture plants. Australian journal of agricultural research 42(1): (in press).

Scott, D.; Charlton, J.F.L. 1983. Birdsfoot trefoil (Lotus corniculatus) as a potential dryland herbage legume in New Zealand. Proceedings of the NZ Grassland Association 44: 98-105.

Stafford, H.A.; Lester, H.H. 1986. Proanthocyanidins in needles from six genera in the Taxodiaceae. American journal of botany 73: $1555-1562$.

Widdup, K.H.; Keoghan, J.M.; Ryan, D.L.; Chapman, H. 1987. Breeding Lotus corniculatus for south island tussock country. Proceedings of the NZ Grassland Association 48: 119-124. 